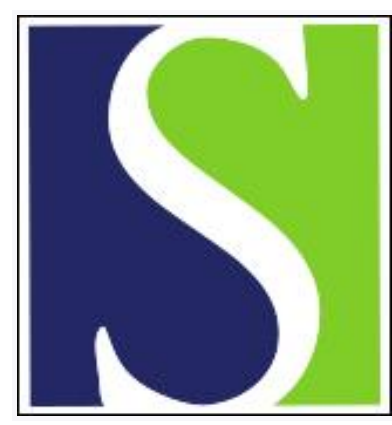

Scand J Work Environ Health 1978;4(2):179-183

https://doi.org/10.5271/sjweh.2710

Issue date: Jun 1978

Relation between radiological pleuropulmonary changes, clinical history and weight index of construction workers.

by Askergren A, Szamosi A

Key terms: asbestos; clinical history; construction worker; extrapleural fat; photofluorography; pleural plaque; pleural thickening; radiological change; radiological pleuropulmonary change; weight index

This article in PubMed: www.ncbi.nlm.nih.gov/pubmed/684392 


\title{
Relation between radiological pleuropulmonary changes, clinical history and weight index of construction workers
}

\author{
by A. ASKERGREN, M.D., ${ }^{1}$ and A. SZAMOSI, M.D. ${ }^{2}$
}

\begin{abstract}
ASKERGREN, A. and SZAMOSI, A. Relation between radiological pleuropulmonary changes, clinical history and weight index of construction workers. Scand. $j$. work environ. \& health 4 (1978) 179-183. Photofluorography was performed on 1,542 male construction workers in the Stockholm area. Postero-anterior, lateral and two anterior oblique views were obtained. The pleural and pulmonary changes found were classified into six groups. The results were correlated to the subjects' calculated weight index and to the occupational history of asbestos exposure and previous lung or pleural disease. There was a strong positive association between a high weight index and changes interpreted as increased amount of extrapleural fat. There was also a positive association between irregular pleural thickenings and adhesions located mainly around the base of the lung and a clinical history of pleural or pulmonary disease. The importance of taking other etiological factors than exposure to asbestos dust into consideration is emphasized when pleural changes are detected in apparently healthy people.
\end{abstract}

Key words: asbestos, construction workers, extrapleural fat, photofluorography, pleural plaque, pleural thickening, weight index.

It is generally accepted that exposure to asbestos dust can result in pulmonary interstitial fibrosis and mesothelioma. It is also known that pleural hyaline plaques and other pleural changes occur with increased frequency in persons exposed to asbestos dust.

The purpose of the present study was to determine the possible association between pleural changes detected by chest roentgenography in healthy adult construction workers and the age, body weight

1 The Foundation for Occupational Safety and Health in the Construction Industry, Bromma, Sweden.

2 Department of Thoracic Radiology, Karolinska Hospital, Stockholm, Sweden.

Reprint requests to: Dr. A. Askergren, The Foundation for Occupational Safety and Health in the Construction Industry (Bygghälsan), Mariehällsvägen 44, S-161 71 Bromma, Sweden. and clinical history of the subjects, as well as the connection to occupational history of exposure to asbestos dust.

\section{MATERIAL}

Wall posters were placed at large construction sites in the Stockholm area. Volunteers were invited to participate in the investigation at no charge $A$ total of 1,615 male workers volunteered. Seventythree of the volunteers were excluded because a complete radiological examination or clinical history could not be obtained.

\section{METHODS}

The subjects were questioned about their clinical and occupational history, special attention being given to previous lung or 
pleural disease and occupational exposure to asbestos. A weight index was obtained by dividing the actual weight of the patient by the average normal weight for individuals of identical sex, age and height (6). Photofluorography of the chest was performed with an Old Delft Odelca 100 camera. For every subject posteroanterior, lateral, and right and left anterior oblique views at $25-30^{\circ}$ were obtained. All exposures were at $140 \mathrm{kV}$. All films were examined by one of us (A. S.) and any pleural changes were classified by appearance and location, without knowledge of any other data concerning the patient. The findings were classified into one of the following groups:

\section{Group I. No changes.}

Group II. Increased distance between the lung and the imaginary line connecting the inner surface of the ribs around the upper lobes of the lungs, with bilateral symmetry and a regular, sharp, smooth margin against the lung. This finding was assumed to represent an increased amount of extrapleural fat.

Group III. The same as group II, but not located around the apex and/or without bilateral symmetry of the thickened soft tissues. This finding was considered possibly to represent a local accumulation of extrapleural fat or pleural thickening.

Group IV. Irregularly shaped, circumscribed, noncalcified, cushionlike thickening of the soft tissues on the inner thoracic wall, laterally, anteriorly, posteriorly, or on the diaphragm, symmetrical or asymmetrical, sparing the costophrenic sinuses. This finding was considered probably to represent a hyaline plaque.
Group V. The same as group IV, but with calcification.

Group VI. Irregular pleural thickening with extension into intrapulmonary septa and adhesions with a predominantly basal location and involving the costophrenic sinus. These changes were considered probably to represent residua of exudative pleurisy.

Adhesions and thickenings with or without calcifications, with nonbasal localizations, and not involving the costophrenic sinuses, were classified as group IV.

\section{RESULTS}

Table 1 shows the age distribution of the sample.

Table 2 shows the association between frequencies of pleural changes and age. The overall frequency of these changes increased with age.

As shown in fig. 1 , there was a positive association between the radiologically detected pleural changes of type VI and a

Table 1. Age distribution of population under study.

\begin{tabular}{lcc}
\hline \multirow{2}{*}{ Age (years) } & \multicolumn{2}{c}{ Patients } \\
\cline { 2 - 3 } & Number & Percentage \\
\hline$\geq 39$ & 912 & $59 \%$ \\
$40-49$ & 259 & $17 \%$ \\
$\geq 50$ & 371 & $24 \%$ \\
\hline Total & 1,542 & \\
\hline
\end{tabular}

Table 2. Frequency of roentgenological findings in the various age groups. Relative frequencies within the corresponding age group are given in parentheses.

\begin{tabular}{|c|c|c|c|c|c|c|c|c|}
\hline \multirow{3}{*}{$\begin{array}{l}\begin{array}{l}\text { Age } \\
\text { (years) }\end{array} \\
\leq 39\end{array}$} & \multirow{3}{*}{$\begin{array}{l}\text { Number of } \\
\text { individuals }\end{array}$} & \multirow{2}{*}{$\begin{array}{l}\text { Pathological chan- } \\
\text { ges in the lungs }\end{array}$} & \multicolumn{6}{|c|}{ Pathological changes in the pleura } \\
\hline & & & \multicolumn{2}{|c|}{$\begin{array}{l}\text { Groups } \\
\text { II--III }\end{array}$} & \multicolumn{2}{|c|}{$\begin{array}{l}\text { Groups } \\
\text { IV-V }\end{array}$} & \multicolumn{2}{|c|}{$\begin{array}{c}\text { Group } \\
\text { VI }\end{array}$} \\
\hline & & $41 \quad(4 \%)$ & 7 & $(1 \%)$ & 6 & $(1 \%)$ & 15 & $(2 \%)$ \\
\hline$\overline{40}-49$ & 259 & $43(17 \%)$ & 25 & $(10 \%)$ & 9 & $(3 \%)$ & 6 & $(2 \%)$ \\
\hline$\geq 50$ & 371 & $105(28 \%)$ & 46 & $(12 \%)$ & 31 & $(8 \%)$ & 25 & $(70 / 0)$ \\
\hline Total & 1,542 & $189(12 \%)$ & 78 & $(5 \%)$ & 46 & $(3 \%)$ & 46 & $(3 \%)$ \\
\hline
\end{tabular}




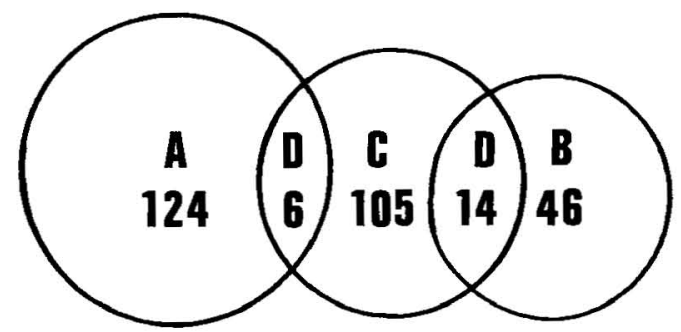

Fig. 1. Association between pleural changes detected in the radiological examination of the chest and the clinical history of pleural or pulmonary disease. [ $A=$ total number of positive radiological findings, group II-V (fat and/ or plaques); $\mathrm{B}=$ total number of positive radiological findings, group VI (postpleurisy); $\mathbf{C}=$ total number of positive histories of plural or pulmonary disease; $\mathrm{D}=$ total number with both a positive radiograph and a positive history of pleural or pulmonary disease]

Table 3. Occupational exposure to asbestos.

\begin{tabular}{lcc}
\hline $\begin{array}{l}\text { Age } \\
\text { (years) }\end{array}$ & $\begin{array}{l}\text { Number of individuals } \\
\text { aware of exposure/total } \\
\text { number in the age group }\end{array}$ & $\% / 0$ \\
\hline$\leq 39$ & $58 / 912$ & 6 \\
$40-49$ & $20 / 259$ & 8 \\
$\geq 50$ & $33 / 371$ & 9 \\
\hline Total & $111 / 1,542$ & 7 \\
\hline
\end{tabular}

clinical history of pleural or pulmonary disease. There was no correlation between such history and pleural changes of other types.

There was no major difference in the history of occupational exposure to asbestos, as reported by the subjects, between the various age groups (table 3 ).

Table 4 shows the distribution of pleural changes of type IV and V (plaques) by age and their association with known occupational exposure to asbestos. Almost all the changes were in subjects who, by history, had not been exposed to asbestos. The same lack of association was found between other types of pleural changes and occupational exposure to asbestos.

Tables 5 and 6 show the association between weight index, age and pleural changes of type II, III and VI. There was a positive association between pleural changes of type II (interpreted as extrapleural fat) and weight index. This association was even more marked when the subgroup of persons with a weight index greater than 120 was considered alone. Thus, 19 out of 42 persons $(45 \%)$ with pleural changes, group II, had a weight index of $>120$. Out of the total population $(1,547)$ only $177(11.5 \%)$ fell into this weight index group. The 19

Table 4. Relation between pleural changes in group IV and V (hyaline plaques and calcified plaques), group VI (postpleurisy), age and known occupational exposure to asbestos.

\begin{tabular}{lcccccccc}
\hline $\begin{array}{l}\text { Age } \\
\text { (years) }\end{array}$ & $\begin{array}{c}\text { Group } \\
\text { IV }\end{array}$ & $\begin{array}{c}\text { Occu- } \\
\text { pational } \\
\text { exposure }\end{array}$ & $\begin{array}{c}\text { Group } \\
\text { V }\end{array}$ & $\begin{array}{c}\text { Occu- } \\
\text { pational } \\
\text { exposure }\end{array}$ & $\begin{array}{c}\text { Total } \\
\text { number } \\
\text { of } \\
\text { plaques }\end{array}$ & $\begin{array}{c}\text { Occu- } \\
\text { pational } \\
\text { exposure }\end{array}$ & $\begin{array}{c}\text { Group } \\
\text { VI }\end{array}$ & $\begin{array}{c}\text { Occu- } \\
\text { pational } \\
\text { exposure }\end{array}$ \\
\hline$\leq 39$ & 4 & 0 & 2 & 0 & 6 & 0 & 15 & 1 \\
$\mathbf{4 0 - 4 9}$ & 7 & 0 & 2 & 0 & 9 & 0 & 6 & 0 \\
$\geq 50$ & 27 & 2 & 4 & 0 & 31 & 2 & 25 & 2 \\
\hline Total & 38 & 2 & 8 & 0 & 46 & 2 & 46 & 3 \\
\hline
\end{tabular}

Table 5. Distribution of weight index by age. Relative frequencies within the corresponding age group are given in parentheses.

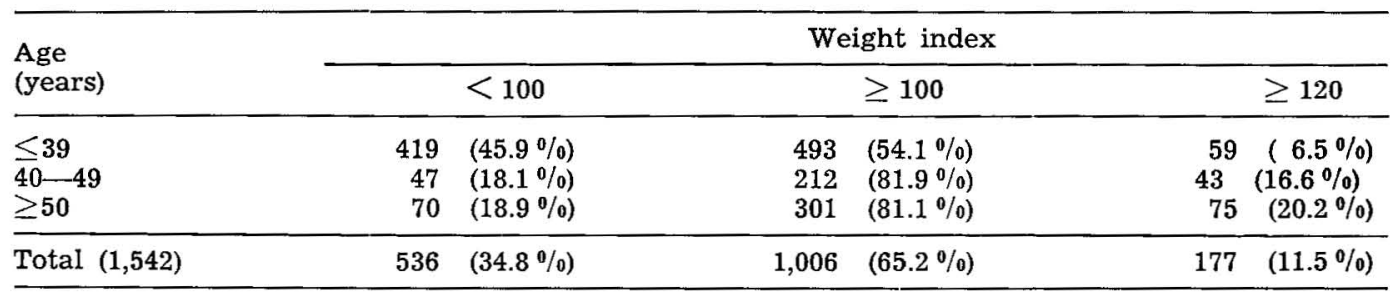


Table 6. Frequency of pleural and pulmonary changes within various age and weight index groups. Relative frequencies within the corresponding age weight index group (see table 5) are given in parentheses.

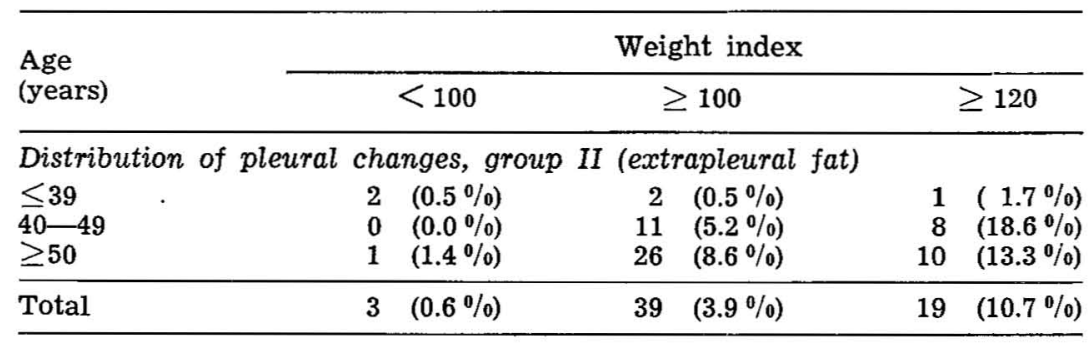

\begin{tabular}{lclllll} 
Distribution of pleural changes, group & III (possible extrapleural fat) \\
$\leq 39$ & 0 & $(0.0 \%)$ & 3 & $(0.6 \%)$ & 1 & $(1.7 \%)$ \\
$40-49$ & 4 & $(8.5 \%)$ & 10 & $(4.7 \%)$ & 3 & $(7.0 \%)$ \\
$\geq 50$ & 1 & $(1.4 \%)$ & 18 & $(6.0 \%)$ & 5 & $(6.7 \%)$ \\
\hline Total & 5 & $(0.9 \%)$ & 31 & $(3.1 \%)$ & 9 & $(5.1 \%)$ \\
\hline
\end{tabular}

\begin{tabular}{|c|c|c|c|c|c|}
\hline $\begin{array}{l}\leq 39 \\
40-49 \\
\geq 50\end{array}$ & $\begin{array}{rr}12 & (2.9 \%) \\
2 & (4.3 \% \%) \\
9 & (12.9 \%)\end{array}$ & $\begin{array}{r}3 \\
4 \\
16\end{array}$ & $\begin{array}{l}(0.6 \%) \\
(1.9 \%) \\
(5.3 \%)\end{array}$ & $\begin{array}{l}0 \\
1 \\
5\end{array}$ & $\begin{array}{l}(0.0 \%) \\
(2.3 \%) \\
(6.7 \%)\end{array}$ \\
\hline Total & $23(4.3 \%)$ & 23 & $(2.3 \%)$ & 6 & $(3.4 \%)$ \\
\hline
\end{tabular}

individuals comprise $10.7 \%$ of the total population (177) with a weight index of $>120$. The corresponding figure for those with pleural changes of group VI was $3.4 \%$, i.e., $13 \%$ of the 46 persons with pleural changes of this type. Nor was there any positive association between weight index and other types of pleural changes (group IV and V), or between weight index and pulmonary parenchymal changes.

Two subjects had pulmonary changes consistent with mild pulmonary interstitial fibrosis. They had no history of occupational exposure to asbestos. No case of pleural mesothelioma or pulmonary malignancy was detected.

\section{DISCUSSION}

At the time of the present survey there were approximately 28,000 construction workers employed in the Stockholm area. The subjects included in the study constituted somewhat more than $5 \%$ of this figure. The sample cannot be considered representative of the total population of construction workers in the area for at least two reasons. First, the subjects participated on a voluntary basis. Second, the investigation only involved persons from large construction sites employing at least 100 workers. The average age of the workers on such sites is known to be below that of the total construction worker population. This age bias by itself could result in a falsely low prevalence of pleural changes of any type.

The positive association between the changes of type II and obesity (table 6) agrees with the assumption that these changes represent an extrapleural accumulation of fat. It appears that such a thickening of the extrapulmonary soft tissues, even without bilateral symmetry and with nonapical localization, may represent local accumulations of extrapleural fat in many cases. This phenomenon would imply that the differentiation between such changes and noncalcified hyaline plaques on radiological grounds alone can be difficult at times. [Some aspects of the radiological appearance of extrapleural fat have been discussed by Vix (10).]

Irregular pleural thickenings and adhesions located mainly around the base of the lung were considered probably to represent the residua of exudative pleurisy. The positive association between such changes and the clinical history of 
pleural or pulmonary disease given in fig. 1 supports this assumption. The figures correspond closely to those presented by The British Thoracic and Tuberculosis Association of the Medical Research Council Pneumoconiosis Unit (1). Whereas the association between pleural plaques and occupational or environmental exposure to asbestos is generally accepted $(3,5,7,9$, $11)$, it seems that such changes can develop even in people without proved exposure to asbestos $(2,4,8)$. In this material, $7 \%$ of all the subjects acknowledged previous occupational contact with asbestos. Out of those 46 individuals with typical pleural plaques (both calcified and noncalcified) only 2 acknowledged such exposure. The apparent lack of association between typical pleural hyaline plaques and occupational exposure to asbestos can be interpreted in several ways. However, it seems reasonable to assume that construction workers with several decades in the trade are, at least occasionally, exposed to asbestos. The figures presented may therefore reflect a lack of awareness, rather than the true prevalence of exposure. Consequently, no conclusions can be drawn in this respect.

The results of the present study underline the importance of taking other etiologic factors than exposure to asbestos dust into consideration when pleural changes are detected in apparently healthy people in radiological chest examinations.

Received for publication: 11 November 1977

\section{REFERENCES}

1. BRITISH THORACIC AND TUBERCULOSIS ASSOCIATION (BTTA), MEDICAL RESEARCH COUNCIL PNEUMOCONIOSIS UNIT (MRCPU). A survey of pleural thickening: Its relation to asbestos exposure and previous pleural disease. Environ. res. 5 (1972) 142-151.

2. CARTIER, P. Discussion on pleural plaques. Ann. n. y. acad. sci. 132 (1965) 387-388.

3. KIVILUOTO, R. Pleural calcification as a roentgenologic sign of nonoccupational antiphyllite-asbestosis. Acta radiol. suppl. (1960) $494 \mathrm{p}$.

4. KIVILUOTO, R. Pleural plaques and asbestos: Further observations on endemic and other non-occupational asbestosis. Ann. n. y. acad. sci. 132 (1965) 235 p.

5. LANGLANDS, J. H. M., WALLACE, W. F. M. and SIMPSON, M. J. C. Insulation workers in Belfast: 2. Morbidity in men still at work. Br. j. ind. med. 28 (1971) $217-225$.

6. LINDBERG, W., NATVIG, H., RYGH, A. and SVENDSEN, $K$. Höyde- og vektundersökelser hos voksne menn og kvinner. Tidsskr. nor laegeforen. 76 (1956) $361-368$.

7. MATTSSON, S.-B. and RINQVIST, T. Pleural plaques and exposure to asbestos: A clinical material from a Swedish lung clinic. Scand. j. res. dis. suppl. 75 (1970).

8. ROUS, W. and STUDENY, J. Ethiology of pleural plaques. Thorax 25 (1970) 270-284.

9. SELIKOFF, I. J. The occurrence of pleural calcification among asbestos insulation workers. Ann. n. y. sci. 132 (1965) 351-367.

10. VIX, V. A. Extrapleural costal fat. Radiology 112 (1974) 563-565.

11. ZOLOV, C., BURLIKOV, T. and BABEDJAV, L. Pleural asbestosis in agricultural workers. Environ. res. 1 (1967) 287-292. 